\title{
MECHANIZATION OF SUGAR CROPS TRANSPLANTING
}

\author{
A. A. EL-Nakib ${ }^{1}$, H. A. Abdel Mawla ${ }^{2}$, A. K. Zaalouk $^{3}$ \\ and W. A. Mahmoud ${ }^{4}$
}

\section{ABSTRACT}

The main aim of this research was study the factors affecting the mechanical transplanting of main sugar crops related to development a single row transplanter prototype to fit the conditions of the Egyptian agriculture. Sugar cane is planted once every four or five year, and use of the transplanter prototype in transplanting sugar beet crop increases the number of annual operating hours and reduces the machine operation costs. The field experiments of the transplanter were conducted at four forward speeds of $(0.7,0.9,1.2$ and $1.4 \mathrm{~km} / \mathrm{h})$ and included the energy required, actual field capacity, field efficiency, actual in-row spacing, and missing hills percentage. Final results show that the average lower actual seedlings spacing 41.5 and $20.6 \mathrm{~cm}$ at forward speed $0.7 \mathrm{~km} / \mathrm{h}$ for theoretical seedlings spacing $40 \mathrm{~cm}$ (sugar cane) and $20 \mathrm{~cm}$ (sugar beet) respectively, lowest values of missed seedlings (1.28\%) and (1.53\%) at forward speed of $0.7 \mathrm{~km} / \mathrm{h}$ for crops of sugar cane $(\lambda=0.262)$ and sugar beet $(\lambda=0.525)$, Maximum field efficiency of transplanter was $82 \%$ and $76 \%$ at forward speed $0.7 \mathrm{~km} / \mathrm{h}$ crops in case of sugar beet and sugar cane respectively and the transplanting costs were 830 L.E. and 597 L.E. per feddan with forward speeds $0.7 \mathrm{~km} / \mathrm{h}$ for sugar beet and sugar cane crops respectively.

Keywords: mechanical transplanting, sugar crops, transplanting, missing hills, field efficiency, in-row spacing, transplanter performance.

\footnotetext{
${ }^{1}$ Prof. emeritus of Fac. of Agric. Eng, AL-Azhar Univ. Cairo.

${ }^{2}$ Prof. and head of Agric. Eng. Dep., Fac. of Agric., AL-Azhar U. Assiut.

${ }^{3}$ Prof. and head of Agric. Pwer \& mach. Eng. Dep., Fac. of Agric. Eng, AL-Azhar Univ. Cairo.

${ }^{4}$ Assis. Lecturer, Agric. Eng. Dep., Fac. of Agric., AL-Azhar U. Assiut.
} 


\section{INTRDODUCTION}

The sugar industry in Egypt and many countries around of the world depend on the two basic crops are Sugar cane (Saccharum

officinarum L.) and sugar beet (Beta vulgaris, L). Area of Sugar cane in Egypt reached up to (332) thousand feddan, with average production of (48.9) ton per fed., and the total planted area of sugar beet in Egypt reached up to (423) thousand feddan, with an average production of (21.5) ton per fed., Egypt produces about 2.29 million tons of sugar from cane and beet sugar crops (CCSC, 2015). The main objective of introducing transplanting technique is to save at least high amount of seed/fed and reduce the duration of sugar crops production season and to save quantity of irrigation water through duration of nursery planting. Transplanting sugar crops seedlings in the main field is exhaustible, irregular, slow and tedious operation. Consequently, the transplanting technique has not been applied at the farmers' fields. Actually, farmers accepted the technique because of its multiple advantages but they have been locking for suitable machine to facilitate easier application of sugar crops transplanting. In the sugar cane transplanting technique, seedlings are raised in a nursery bed using single bud sets. Then, when the seedlings are of about 6-8 weeks old, they are transplanted in the prepared main field, and in the sugar beet transplanting technique seeds are planted in paper pots before they are transplant in the field. Jakeway (1985) indicated that "Automatic detection of seed cane nodes and/or eyes are technically feasible". The radio frequency, (RF) absorption method can locate nods with leafy trash still attached to the stalks at very fast detection rates, but this method requires different size coupling coils, complicating the design for a production system. The machine vision method cane detects nodes and eyes at considerably slower rates. Sundara (1998) Mention that advantages of the sugarcane transplanted is:

1. Saving in the seed cost as the seed requirement is only about 2.3 ton/ha in this system as against 8-10 ton used in the normal planting.

2. Synchronous tillering, leading to uniformly matured stalk population, which usually gives, better sugar recovery. 
3. Sufficient time availability to prepare the main field.

4. Saving of 2-3 irrigations.

5. Saving of around 20-30 days in the main field duration

6. Possibility of increased cane yield.

7. Efficient fertilizer management.

8. Better weed management.

Drees (2005) recommended that the sugarcane transplanting could be used as alternative method of the sugarcane seedlings. They could be prepared inside the plastic pots to maintain on the roots and decrease the percentage of the dead seedlings. In the future, it is recommended that development and construction of a specially transplanter for the sugarcane crop. Ismail and Ghatas (2009) found that the best results for sugar beet transplanting were obtained using feed metering speed of $0.16 \mathrm{~m} / \mathrm{s}$. The maximum field efficiency of $94.5 \%$ was obtained at forward speed of 1.5 $\mathrm{km} / \mathrm{h}$ and the minimum field efficiency of $83.2 \%$ was obtained at forward speed of $4.2 \mathrm{~km} / \mathrm{h}$.

Abd El-Mawla et al. (2011) developed a sugarcane transplanter and found that the best of the results for sugar cane transplanting could be using the $0.9 \mathrm{~km} / \mathrm{h}$. forward speed, $40 \mathrm{~cm}$ distance between seedlings and 60 days age of seedlings for seedlings planted in plastic bags, and using the $0.6 \mathrm{~km} / \mathrm{h}$ forward speed, $40 \mathrm{~cm}$ distance between seedlings and 50 days age of seedlings for seedlings planted directly in nursery. The maximum of field efficiency was $86 \%$ when the forward speed $0.6 \mathrm{~km} / \mathrm{h}$ and minimum of field efficiency was $51 \%$ when the forward speed 1.50 $\mathrm{km} / \mathrm{h}$.

\section{MATERIAL AND METHODS}

\section{- Materials:}

Nursery's establishing:

a) Cane stalks characteristics.

The feddan is need about of $1600 \mathrm{~kg}$ from sugar cane stalks suitable for agriculture for obtaining bud sets, characteristics discussion of cane seed stalks used for obtaining of buds are presented in Table (1). 
Table (1): Characteristics of sugarcane C-9 variety stalk before buds separation.

\begin{tabular}{|l|c|}
\hline Average characteristics & Mean \\
\hline Stalk length "L" cm & 295 \\
\hline Stalk diameter "D" cm & 2.35 \\
\hline Stalk mass "M" kg & 1.95 \\
\hline The number of buds on stalk & 16 \\
\hline No. of buds at fed. (In-row spacings $=40 \mathrm{~cm}$ ). & 12000 \\
\hline
\end{tabular}

\section{b) Planting sets of buds.}

The planting nursery of area was $25 \mathrm{~m}^{2}$ with $500 \mathrm{~kg}$ sugarcane stalks to give buds enough for planting this area. Nursery was established by planting sets with intact buds as planting single bud in plastic bags $(6 \times 13$ $\mathrm{cm})$. The nursery was planted with sugar cane C-9 variety in the first week of March 2015.

\section{c) Planting seeds of sugar beet.}

The nursery of sugar beet seeds "Helna-variety" of mono-germs seeds variety were planted in September 2015. Nursery area was about $30 \mathrm{~m}^{2}$, seeds planted in paper pot trays.

\section{d) Seedlings:}

1) Sugar cane seedlings 6-8 weeks which it's mass were about $150 \mathrm{gm}$.

2) Sugar beet seedlings 4-6 weeks and mass were about $60 \mathrm{gm}$. Average characteristics of sugar cane and sugar beet seedlings listed in Table (2) and shown in Figures (1) and (2).

Table (2): Average characteristics of sugar beet and sugar cane seedlings.

\begin{tabular}{|l|c|c|}
\hline \multicolumn{1}{|c|}{ Properties } & $\begin{array}{l}\text { Sugar beet } \\
\text { seedlings }\end{array}$ & $\begin{array}{l}\text { Sugar cane } \\
\text { seedlings }\end{array}$ \\
\hline Seedlings total length, mm & 201 & 590 \\
\hline Stem thickness, mm & 1.55 & 5.21 \\
\hline Stem length, mm & 50.2 & 150 \\
\hline Length of root, mm & 99.8 & 80 \\
\hline Ave. number of leaves & 2.8 & 6.8 \\
\hline
\end{tabular}




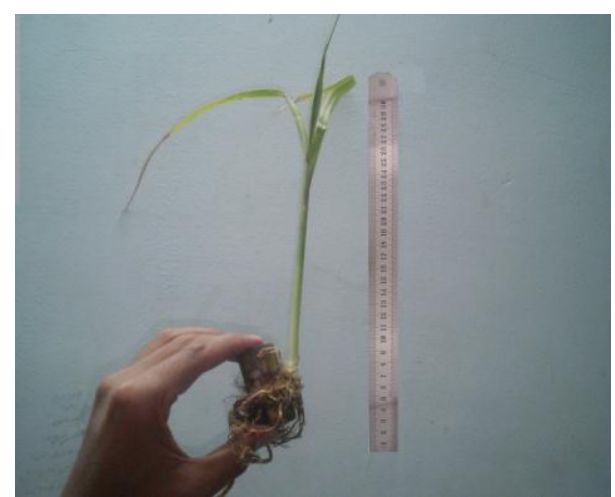

Fig. (1): Sugar cane seedling at six weeks age.

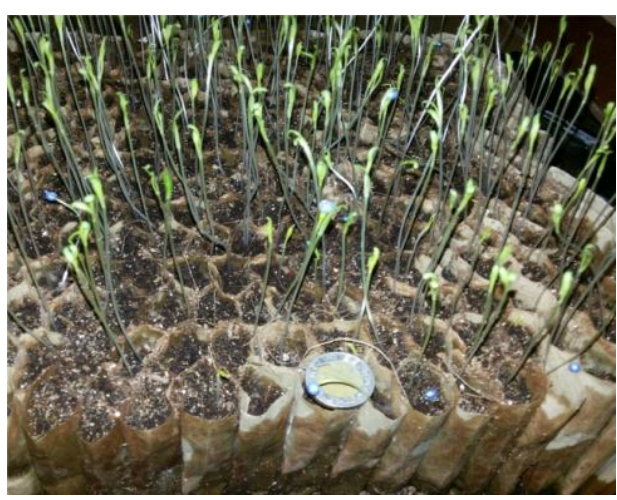

Fig. (2): Sugar beet seedlings at 10 days age after planting in paper pots.

\section{Transplanter}

The tractor is attached one row transplanter require one labor feeding. The transplanter prototype developed for sugar cane transplanting in the main field, and can adjusted to use with sugar beet transplanting. The machine contains a mechanical feeding unit developed to eliminate the problem of missing hills by the labor. The transplanter prototype of mass $200 \mathrm{~kg}$ and consists of the following parts, as shown in Figure (3).

\section{Feeding mechanism.}

Feeding mechanism consist of two units for mechanical feed to overcome missing the seedlings by the labor.

The feeding mechanism is show in Figures (4) consists of the following parts:

\section{a. Feeding belt:}

A flat belt that is moves vertical axis on a horizontal plan by two rollers. The drive roller (1) powered by ground-wheel through transmission arrangement. The belt is $228 \mathrm{~cm}$ length, $11 \mathrm{~cm}$ width and $5 \mathrm{~mm}$ thickness.

\section{b. Cells:}

24 cells are distributed on the perimeter of the belt so that the distance between every two cells $10.5 \mathrm{~cm}$, which are made of metal sheet as a concave shape, fixed and tilted backward with angle of 60 degrees on the horizontal of the belt.

Figure (5) illustrate the analysis of weight force for seedling depended on inclined angle of 60 degrees for cells. 

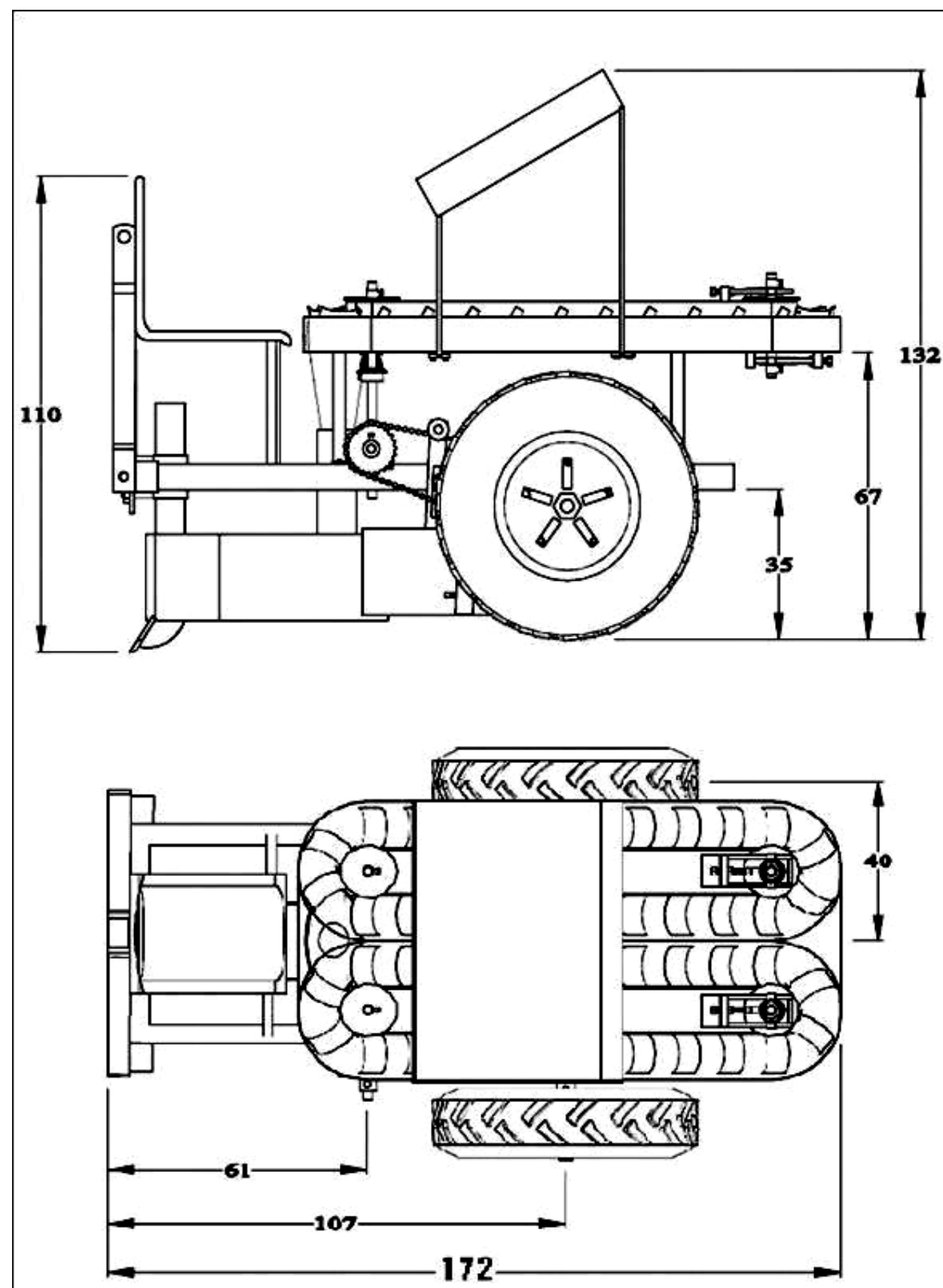

Dims. in cm.

Fig. (3): Elevation and plan of the developed transplanter prototype. 


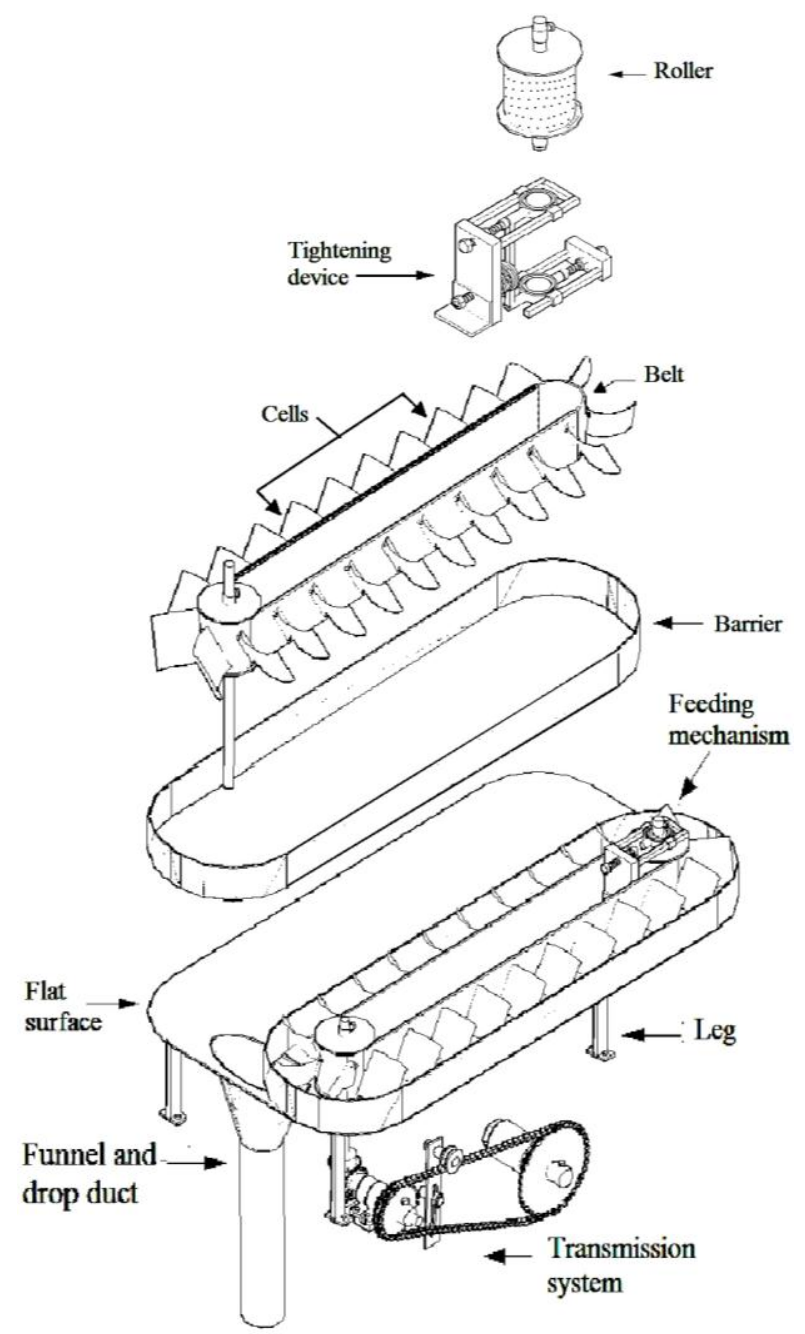

Fig. (4): The feeding mechanism in details.

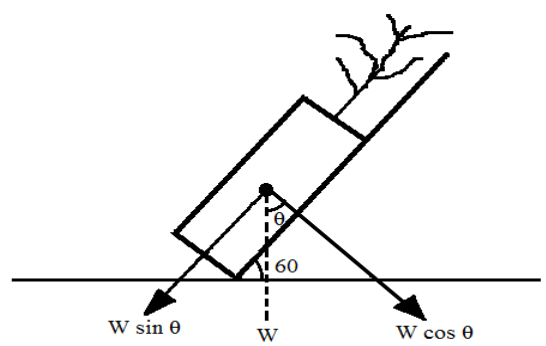

Fig. (5): Analysis of weight force for seedling depended on inclined angle of 60 degrees. 
Through of practical experimental for comparison of angle 45, 50 and $60^{\circ}$ to determining of optimum angle for dropping of seedlings in the funnel and drop duct, was notes that exposure of the funnel and drop duct to occlusion because of inclined dropping of seedling. And was noted the best of angle to vertical dropping for seedlings was $60^{\circ}$.

\section{c. Rollers and tightening device:}

The feeding mechanism contains of four rollers (two rollers per the belt), the length of roller $12 \mathrm{~cm}$, and the outside diameter of $12 \mathrm{~cm}$ and fitted with two edges in order to adjust and safe the belt path. The surface of rollers that move the belt is a provided with many protrusions for reduced of slipping.

Each roller move of on axis attached on ball bearings. The front roller (the driver) is move by transmission group. The back rolls (the driven) provide with tightening device to tighten the belt to the extent required.

\section{Flat surface:}

The surface constructed for carrying the belt, rolls mechanism and seedlings. Rectangular metal sheet of $3 \mathrm{~mm}$ thickness attached the main frame has four legs a height of $28 \mathrm{~cm}$.

\section{Funnel and drop duct:}

A funnel and drop duct is located at the front of the flat surface. Seedlings fall into the funnel from cells both of feeding belts, and drop through the drop duct has $7.5 \mathrm{~cm}$ in diameter and $40 \mathrm{~cm}$ height and cracked from the back with $30 \mathrm{~cm}$ length to allow with release stems and leafs of seedlings after it falling in the bottom of the furrow.

\section{Furrow-opener.}

The furrow opener has width of $20 \mathrm{~cm}$ and height of $20 \mathrm{~cm}$. The furrow opener is attached to the frame and provider with two wings to remove soil until the seedling fall of the in the furrow as shown in Figure (6).

\section{Covering device.}

A covering device consisted of two inclined steel sheets to collect and cover the seedlings. Covering device can adjusted to form the furrow width required. The covering device has attached to the transplanter frame by square beam of $(5 \times 5) \mathrm{cm}$ as shown in Figure (6). The covering device contains tow opposite steel press rollers with diameter of $6 \mathrm{~cm}$ and height of $15 \mathrm{~cm}$. to press the soil around the seedlings. 

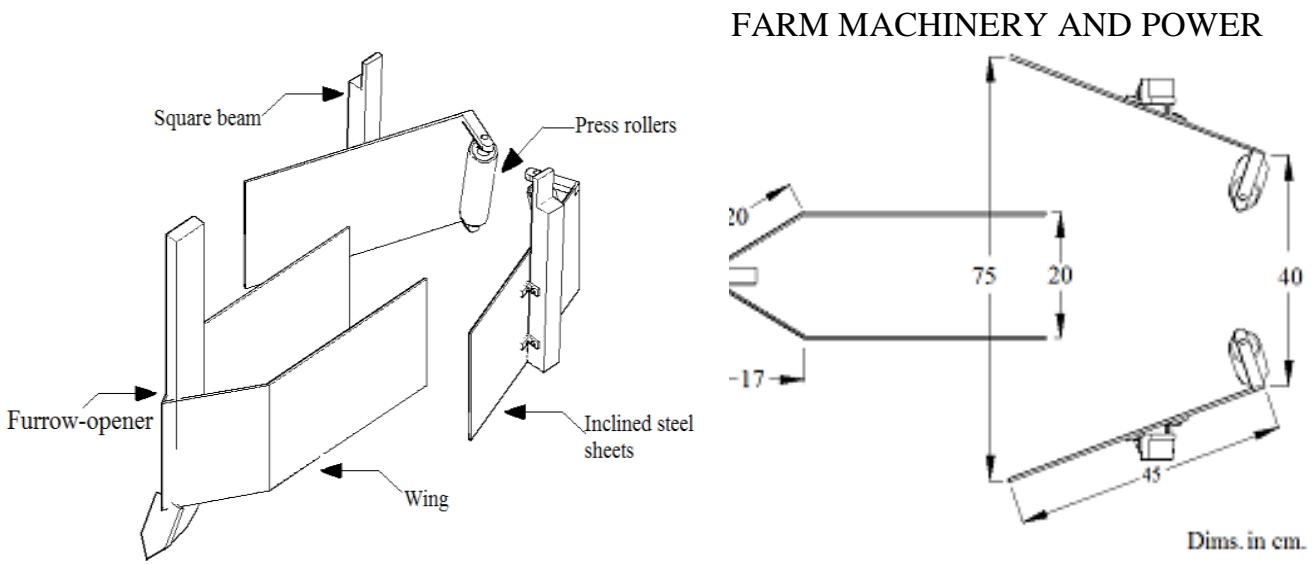

Fig. (6): Furrow-opener and covering devices.

\section{Ground-wheels.}

Two rubber ground-wheels of diameters $60 \mathrm{~cm}$ and $15 \mathrm{~cm}$ width attached with the transplanter frame.

\section{Power transmission system.}

\section{a. Transmission ratio:}

The transmission system depended on the ground wheel movement to move of the feeding mechanism. Figure (7) show the power transported from the ground wheel to cells by groups of gears, a sprockets and chain to achieve equal seedling spacing appropriate each of crops.

Two sprockets and chain are used to transmit the power and motion from the ground wheel to the feeding mechanism for each crop. When in-row spacing of the sugar beet crop the first sprocket has 48 teeth fixed on wheel shaft and drives the other sprocket witch as 16 teeth to move of bevel gears group of the feeding mechanism. While in-row spacing of the sugar cane crop the first sprocket has 38 teeth fixed on wheel shaft and drive the other sprocket witch as 26 teeth to move of bevel gears group of the feeding mechanism. Pressed wheel steel, detachable-link chain is used for attachment between two sprockets. With the help of Figure (3.14) transmission speed can be calculated. Reduction ratio of feeding mechanism to get equal distances between seedlings based on some design considerations assumed are presented in Table (3).

Two ratios between ground wheel and feeding mechanism were designed to accomplish certain seedling spacing. The motion ratio ware 1:3 and 
1:1.47 to 20 and $40 \mathrm{~cm}$ in row spacing for sugar beet and sugar cane crops respectively.

Table (3): The design considerations estimated values for transmission speed calculate of the developed transplanter prototype.

\begin{tabular}{|l|l|}
\hline \multicolumn{1}{|c|}{ Item } & Assumed values \\
\hline Diameter of ground wheel (cm) & 60 \\
\hline Diameter of roller which has belt (cm) & 11 \\
\hline Theoretical seedlings spacing (cm) & 20 and 40 \\
\hline Distances between cells on the belt (cm) & 10.5 \\
\hline Number of cells of one the belt (No.) & 24 \\
\hline
\end{tabular}

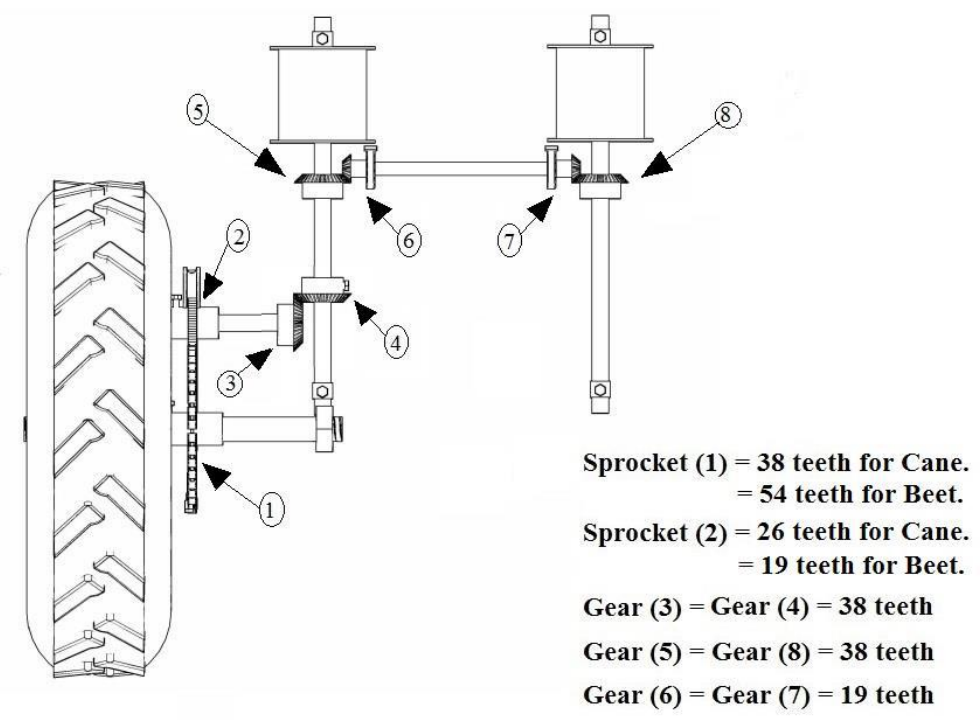

Fig. (7): Transmission system and ground wheel drive.

\section{b. Kinematic index $(\lambda)$ :}

Based on Klenin (1985), the kinematic index $(\lambda)$ of the planter is the ratio of the linear velocity $(u)$ of the extreme point of the clamping of the 
seedling and the speed (v) of the machine that is:

$$
\lambda=\mathrm{u} / \mathrm{v}
$$

The Arrangement of seedlings sets of sprocket and corresponding theoretical seedling spacing and Kinematic index $(\lambda)$ are listed in Table (4).

Table (4): Sprocket arrangement of seedlings sets of and corresponding theoretical seedling spacing.

\begin{tabular}{|l|c|l|l|l|l|}
\hline Crop & $\begin{array}{l}\text { In row } \\
\text { spacing, } \\
\text { cm }\end{array}$ & $\begin{array}{l}\text { No. teeth of } \\
\text { sprocket (1) on } \\
\text { the ground } \\
\text { wheel. }\end{array}$ & $\begin{array}{l}\text { No. teeth of } \\
\text { sprocket (2) on } \\
\text { the feeding } \\
\text { shaft }\end{array}$ & $\begin{array}{l}\text { Motion } \\
\text { ratio }\end{array}$ & $\begin{array}{l}\text { Kinematic } \\
\text { index }(\lambda)\end{array}$ \\
\hline S. beet & 20 & 48 & 19 & $1: 3$ & 0.525 \\
\hline S. cane & 40 & 38 & 26 & $1: 1.47$ & 0.262 \\
\hline
\end{tabular}

\section{Labor seat.}

A labor seat located in front of transplanter rear oriented and fixed on the transplanter frame where easily feed the seedlings in the feeding cells easily.

\section{Seedlings holder.}

The seedling shelf was made of $2 \mathrm{~mm}$ steel sheet with $90 \mathrm{~cm}$ length and $60 \mathrm{~cm}$ width. The capacity of seedling holder is about 150 cane seedlings, which are sufficient to plant two rows of $30 \mathrm{~m}$ length. And about 600 beet seedlings which are sufficient to plant four rows of $30 \mathrm{~m}$ length.

\section{Tractor.}

A tractor (IMT $50 \mathrm{~kW}$ Romanian made) was used to drag the transplanter during the transplanting operation.

\section{Measurements:}

\section{Forward speeds}

Forward speeds were $0.7,0.9,1.2$ and $1.4 \mathrm{~km} / \mathrm{h}$.

\section{In-row spacings.}

The spacings between seedlings measured to determining actual seedlings spacings. 


\section{Slippage percentage.}

The slippage percentage was determined.

\section{Evaluation factors.}

\section{a. Percentage of missing hills, $\%$.}

The Percentage of missed hills (M.h \%) was calculated from equation (2).

$$
\text { M.h\% }=\frac{\mathrm{N}_{1}}{\mathrm{~N}_{2}} \times 100,
$$

Where:

$$
\begin{aligned}
& \text { M.h\% = Percentage of missing hills. \% ، } \\
& \mathrm{N}_{1} \quad=\text { Number of missing hills seedlings at } 30 \text { m row length. } \\
& \mathrm{N}_{2} \quad=\text { The total number of seedlings at } 30 \text { m row length. }
\end{aligned}
$$

\section{b. Dead seedlings percentage.}

$$
\text { D.s }=\frac{\mathrm{N}_{3}}{\mathrm{~N}_{2}} \times 100
$$

Where:

D.s $\%=$ Percentage of dead seedlings.\%

$\mathrm{N}_{3}=$ Number of dead seedlings after from one to three weeks.

$\mathrm{N}_{2}=$ The total number of seedlings in unit area.

\section{Transplanter performance:}

The transplanter was tested for transplanting of sugar cane and sugar beet seedlings of theoretical in-row spacing's 40 and $20 \mathrm{~cm}$ between seedlings and distance between rows was 90 and $60 \mathrm{~cm}$ for crops sugar cane and sugar beet respectively. The length of rows was $30 \mathrm{~m}$ for each of experimental of field treatment.

\section{a. Actual field capacity.}

The theoretical and actual field capacities were determined.

\section{b. Field efficiency $\%$.}

The Field efficiency was determined. 


\section{RESULTS AND DISCUSSION}

\section{Effect of the transplanting forward speed on In-row spacing.}

The average lower actual seedlings spacing 41.5 and $20.6 \mathrm{~cm}$ at forward speed $0.7 \mathrm{~km} / \mathrm{h}$ for theoretical seedlings spacing $40 \mathrm{~cm}$ (sugar cane) and $20 \mathrm{~cm}$ (sugar beet) respectively. The increased seedling spacing by increasing the forward speed may be due to variation of slip ratio of the machine ground speed as affected by the change of forward speed. Figures (8.a) and (8.b) illustrates the average actual seedlings spacing increased by increased the forward speed for all spacings in-row adjusted on the transplanter.

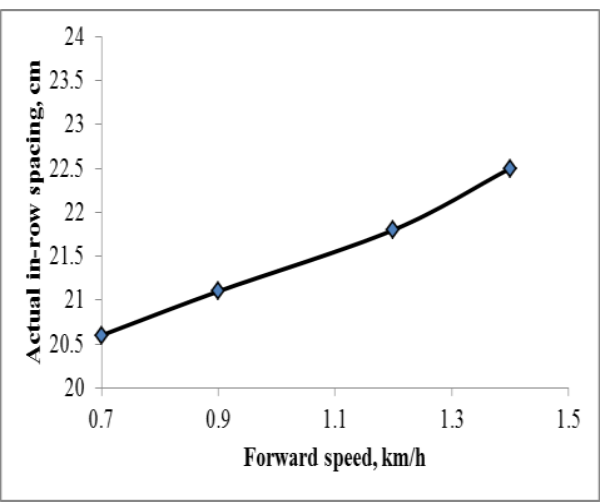

Fig. 8.a: Effect of forward speed on the average seedlings spacing of sugar beet.

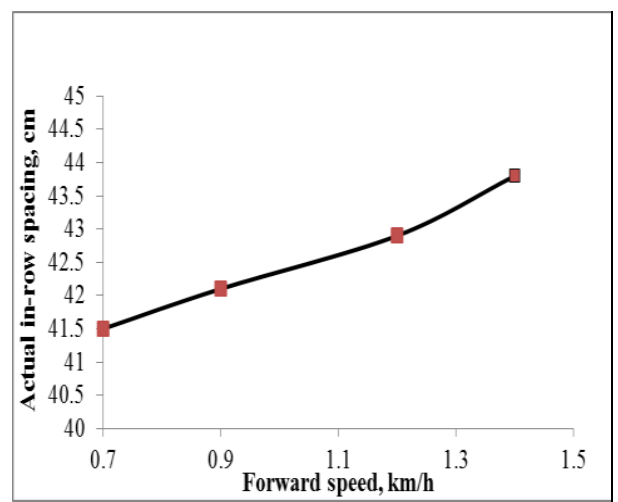

Fig. 8.b: Effect of forward speed on the average seedlings spacing of sugar cane.

\section{Effect of the transplanting forward speed on Missing hills, \%.}

At the higher values of forward speed, the interval of feeding seedlings is shorter and the probability of missing feeding becomes greater specially when $\lambda=0.525$ (for sugar beet crop).

The lowest values of missed seedlings (1.28\%) and (2.67\%) at forward speed of $0.7 \mathrm{~km} / \mathrm{h}$ for crops of sugar cane $(\lambda=0.262)$ and sugar beet $(\lambda=0.525)$, while the highest value of missed seedling $(9.03 \%)$ and (33.33\%) at $1.4 \mathrm{~km} / \mathrm{h}$ forward speeds for crops of sugar cane $(\lambda=0.262)$ and sugar beet $(\lambda=0.525)$. Figure (9) illustrates that the missed seedlings percentage increased by increasing the transplanter forward speed. 


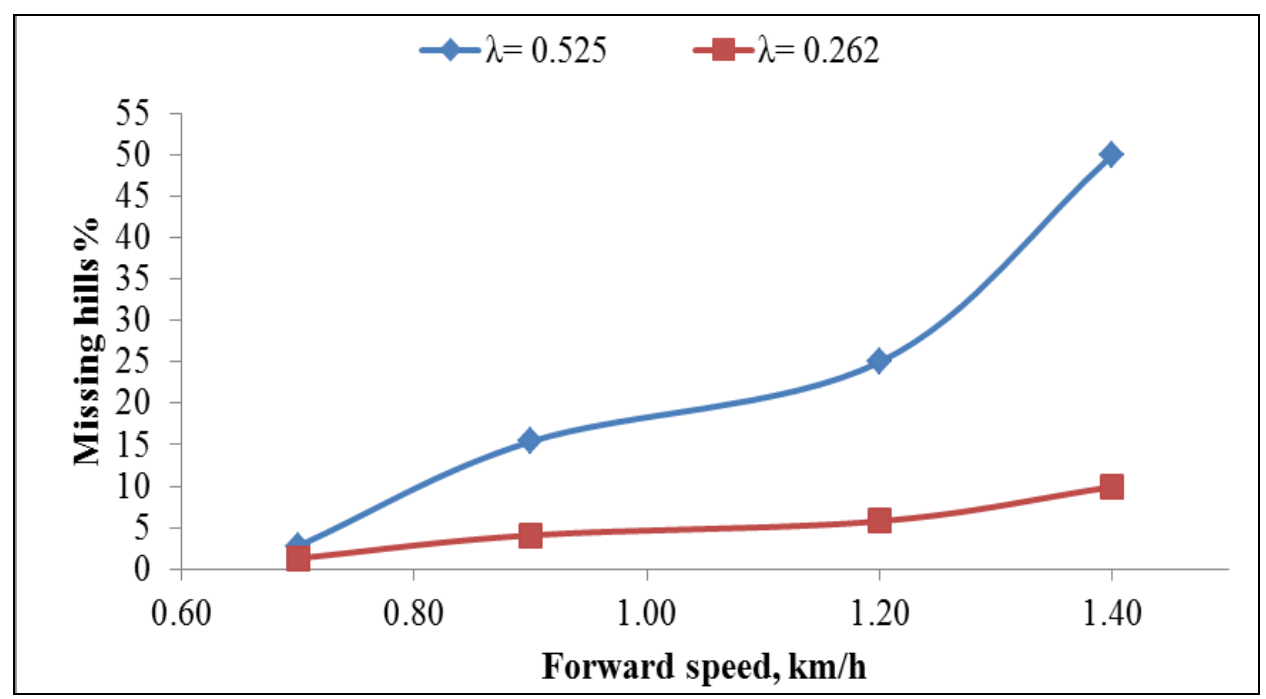

Fig. (9): Missing hills percentage as affected by forward speed for crops of sugar cane and sugar beet.

\section{Effect of the transplanting forward speed on Dead seedlings, $\%$.}

The minimum value of dead seedlings percentage was 1.65 and $1.3 \%$ at $0.7 \mathrm{~km} / \mathrm{h}$ forward speed for both crops sugar cane and sugar beet respectively, and when operating the transplanter the high speed to 1.4 $\mathrm{km} / \mathrm{h}$ that the value of dead seedlings increased to less than 4 and $5 \%$ for sugar cane and sugar beet crops respectively. The dead seedling percentage affected by many factors such as peripheral speed of feeding belt, handling of seedlings by operating laborer, fixed in the soil and feeding rate of seedlings. Figure (10) illustrate increased of dead seedling percentage affected by forward speed after one week of transplanting in the main field.

\section{Slipping of ground wheel ratio.}

From Figure (11) it's clearing that increasing of slipping ratio by $2.0 \%$, $3.8 \%, 5.4 \%$ and $6.5 \%$ when increasing the forward speed from $0.7 \mathrm{~km} / \mathrm{h}$ to $0.9,1.2$ and $1.4 \mathrm{~km} / \mathrm{h}$ respectively. This may be due to the sweeping of crushed soil under transplanter wheel as result of its vibration of transplanter wheels caused by increasing forward speed. 


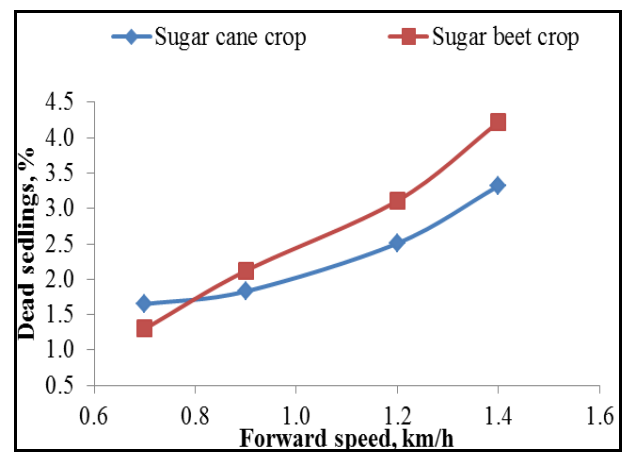

Fig. (10): Dead seedlings percentage affected by forward speed for crops of sugar cane and sugar beet

\section{Transplanter performance.}

The maximum value of transplanter efficiency was $76 \%$ and $82.43 \%$ for transplanting of sugar cane and sugar beet crops respectively under forward speeds of tractor $0.7 \mathrm{~km} / \mathrm{h}$.

\section{Cost analysis.}

Table (5) shows the costs of transplanting operation using the machine prototype for forward speeds $0.7,0.9 \mathrm{~km} / \mathrm{h}$. As shown in the table, the highest transplanting costs were 830 L.E. and 597 L.E. per feddan with forward speeds $0.7 \mathrm{~km} / \mathrm{h}$ for sugar beet and sugar cane crops respectively.

Table 5: Cost per feddan for the transplanting operation using the transplanter prototype.

\begin{tabular}{|l|l|l|l|l|}
\hline \multirow{2}{*}{$\begin{array}{l}\text { Forward } \\
\text { speed, } \\
\mathrm{km} / \mathrm{h}\end{array}$} & $\begin{array}{l}\text { In-row } \\
\text { spacing's, } \\
\text { cm }\end{array}$ & \multicolumn{2}{|l|}{$\begin{array}{l}\text { Actual fapacity } \\
\text { cm }\end{array}$} & $\begin{array}{l}\text { Costs } \\
\text { feddan } \\
\text { transplanting, } \\
\text { L.E. }\end{array}$ \\
\hline \multirow{2}{*}{0.7} & 20 & 0.082 & 12.13 & 830 \\
\cline { 2 - 5 } & 40 & 0.114 & 8.77 & 597 \\
\hline \multirow{2}{*}{0.9} & 20 & 0.101 & 9.91 & 674 \\
\cline { 2 - 5 } & 40 & 0.137 & 7.3 & 497 \\
\hline
\end{tabular}




\section{CONCLUSION}

This research was conducted to evaluate the transplanter of main sugar crops. Results can be concluded that:

1- Average lower actual seedlings spacing 41.5 and $20.6 \mathrm{~cm}$ at forward speed $0.7 \mathrm{~km} / \mathrm{h}$ for theoretical seedlings spacing $40 \mathrm{~cm}$ (sugar cane) and $20 \mathrm{~cm}$ (sugar beet) respectively.

2- Lowest values of missed seedlings (1.28\%) and (1.53\%) at forward speed of $0.7 \mathrm{~km} / \mathrm{h}$ for crops of sugar cane $(\lambda=0.262)$ and sugar beet $(\lambda=0.525)$.

3 - Increase of the transplanter forward speed from 0.7 to $1.4 \mathrm{~km} / \mathrm{h}$ leads to increase slippage percent and dead seedlings percentage.

4- Maximum field efficiency of transplanter was $82 \%$ and $76 \%$ with forward speed $0.7 \mathrm{~km} / \mathrm{h}$ crops of sugar beet and sugar cane respectively.

5- The transplanting costs were 830 L.E. and 597 L.E. per feddan with forward speeds $0.7 \mathrm{~km} / \mathrm{h}$ for sugar beet and sugar cane crops respectively.

\section{REFERENCES}

Abd El Mawla H.A, A.M. El Laithy, A. M. Drees and W.A. Mahmoud (2011). A single row sugarcane trans-planter, Misr J. Ag. Eng., 28 No 4: 441- 454.

Central Council for Sugar Crops (2015). World status of sugar crops, productivity of sugar crops in Egypt. Sugar crops and sugar production in Egypt and the world. Ministry of Agriculture 1:85

Drees, A. M. (2005). A study on mechanization of sugar cane Planting Ph. D. Agric. Eng. Dept. Fac. of Agric., Tanta Univ.: 108 -112.

Ismail, Z. E. and A. S. Ghattas (2009). The semi- automatic transplanter of sugar beet, Misr J. Ag. Eng., 26(3): 1155 - 1171. 
Jakeway, L. A. (1985). Mechanical planting of Sugarcane in small holdind sizes in Egypt. Inter-American sugarcane seminars. Miami volume 1:168-174.

Sundara. B. (1998 ). Sugarcane Cultivation - First Edition pp. 56 -68.

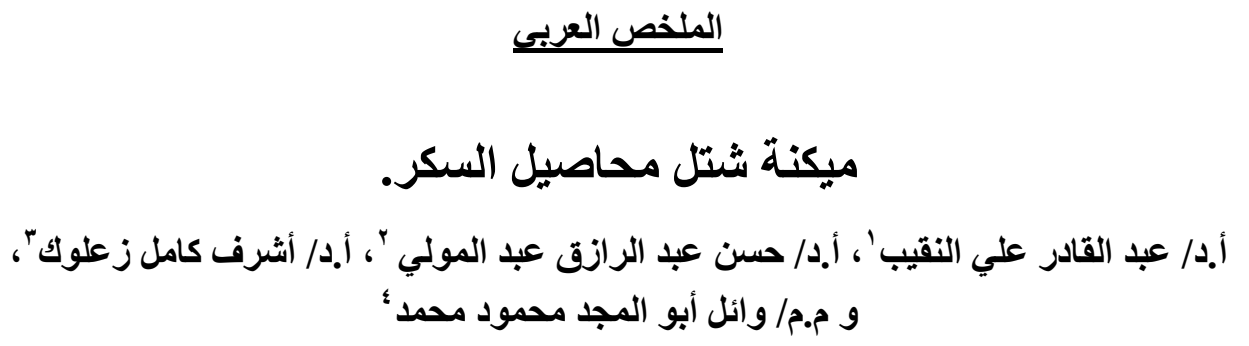

تعتمد صناعة السكر في مصر على محصولين أساسيين هما قصب وبنجر السكر ، وتتتج مصر

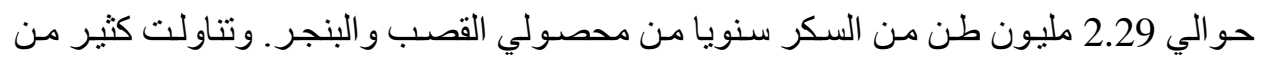

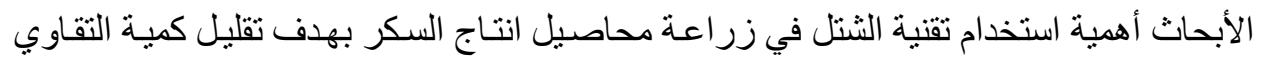

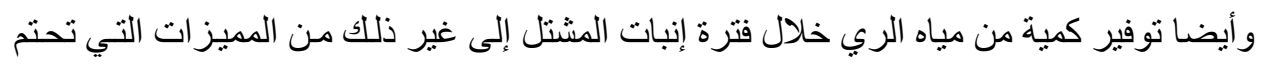

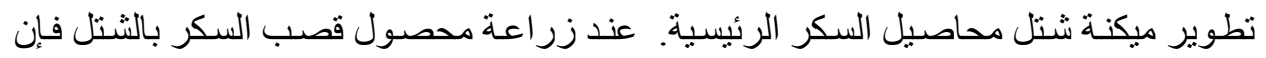

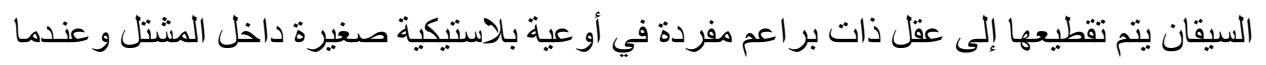

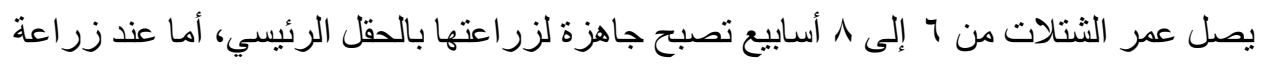

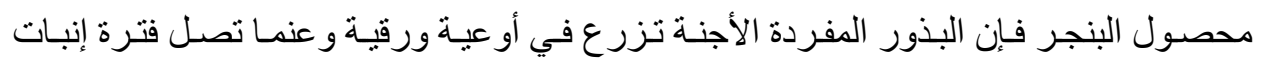
المشتل من ؛ إلى 1 أسابيع فإن الثتلات تكون جاهزة اللثنتل بالحقل الرئيسي.

يهرف البحث إلى دراسـة العوامل المؤثرة على شتل محاصيل السكر الرئيسية ( القصب

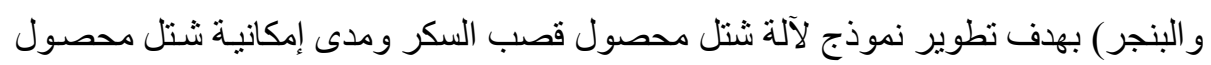

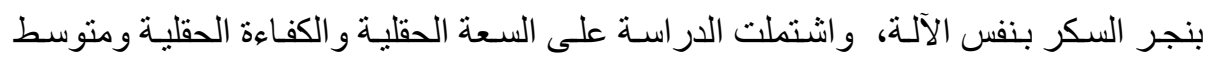

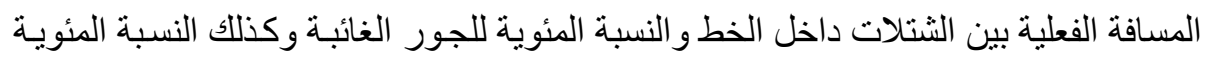
للثتلات الميته بعد الثتل و استهلاك الوقود ومنطلبات الطاقة وتكاليف عملية الثتل.

1-أستاذ الهندسة الزراعية المتفرغ - كلية الهندسة الزراعية جامعة الأزهر بالقاهرة.

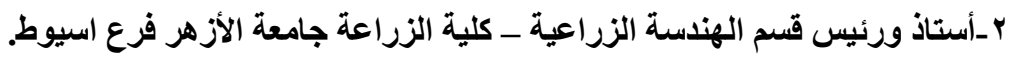

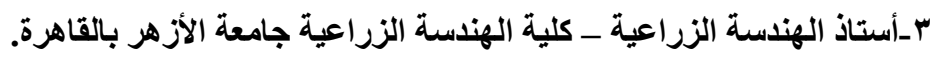

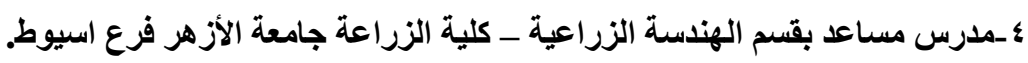




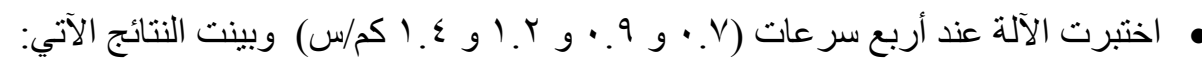

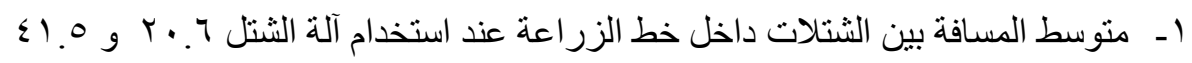

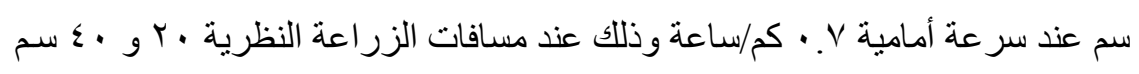
لمحصولي البنجر و القصب على الترتيب.

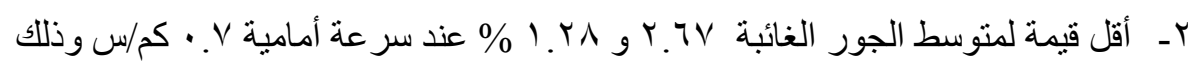
لمحصولي البنجر و القصب على الترتيب.

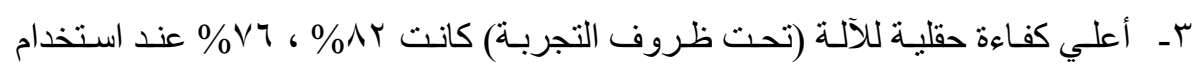

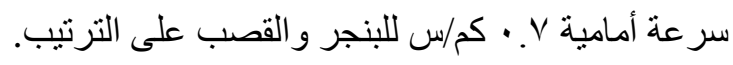

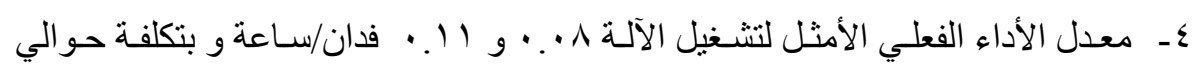

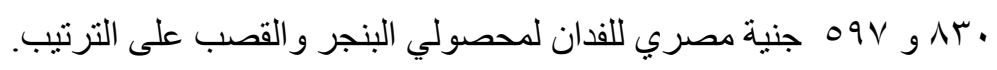

